\title{
鍼治療は脳の活動を活発にする
}

\section{Acupuncture activates the brain}

doi:10.1038/news050425-12/1 May 2005

Andreas von Bubnoff

鍼治療には偽薬効果ではない現実の効果があることが、脳画像診断法で確認された。

鍼治療にはまだ解明されていない点が 多いものの、実際測定可能な影響を脳 に与えることが発見された。鍼治療が 患者の役に立っている理由が、効用に 対する患者の単なる期待感によるもの だけではないという新たな証拠がもた らされたのだ。

サウサンプトン大学（英国）の補完医 学の専門家George Lewithをリーダー とする今回の研究では、本物の鍼を使っ た治療では、銊のように見える偽物を 使った場合よりも多くの脳内領域の活 動が活発になることが、脳画像診断法 によって明らかになった。「これは、鍼 治療に偽薬 (プラシーボ) 効果ではない 現実の効果があることを、脳画像診断 法によって初めて示した研究となった」 と Lewithは語る。

鍼治療は、病気、痛みや依存症に対 する古代中国の治療法で、体の決まっ た場所（ツボ）に細い鍼を刺して行わ れる。鍼治療のメカニズムはほとんど 解明されておらず、これまでに実施さ れた鍼治療の臨床試験の結果もまちま ちであった。「臨床試験によって効果が 認められたり認められなかったりで、 とても複雑になっている」と語るのは、 鍼治療を研究するハーバード大学 (米 国マサチューセッツ州ボストン) の Ted Kaptchukだ。これまで行われた数多 くの研究では、確認された効用のほと んどが偽薬効果によるものであるとい われている。

「このような混乱の一因は、鍼治療の 臨床試験における比較対照試験の計画 が不適切だったことかもしれない」と
複数の専門家は指摘する。たとえば、 一部の臨床試験では被験者にツボでな いところに鍼を刺していた。しかし、 これではツボの問題は反映されず、単 に鍼を刺すことが効果的な治療法であ るかどうかを実証する試験になってし まうだろう。

\section{押すと引っ込む模造鍼}

偽薬効果をみるためのより適切な方法 を使おうと考えた Lewith のチームは、 実際には皮膚に突き刺さらない伸縮自 在の鍼を使って、被験者には鍼が刺さっ ていると思わせる方法を用いた。「この 鍼は、舞台で使われる小道具の短剣のよ うに、鍼の先を押すと鍼が柄の中に引っ 込むようになっている」と Lewith は説 明する。これにより、被験者は自分が 鍼治療を受けていると思い込んだの だった。もちろん、実際はそうではない。 被験者グループは親指に関節痛のあ る 14 人の患者で、上記の偽薬治療と 本物の鍼治療に加えて、先がとがって おらず皮膚に突き刺さらない鍼を使っ た鍼治療類似行為の 3 種類を受けた。 最後のケースでは、この行為に何の効 果もないことが被験者にあらかじめ告 げられた。

次に Lewith たちは、陽電子放射断層 撮影法を使って、脳の活動を測定した。 すると、偽薬治療を受けた場合も本物 の鍼治療を受けた場合も、オピエート に反応することが知られる脳内領域の 活動が活発になった。ここで、オピエー トとは脳内で分泌される物質で、鎮痛 作用がある。
「島」の活動が活発になる 本物の鍼治療を行うと、大脳皮質の一 部である「島」という領域の活動も活発 になった。Lewith は「この活動が何 を意味しているのかは明らかでないが、 鍼治療による何らかの現実の作用があ ることを示している。今回の研究で実証 されたのは、鍼治療の効果は一部が期 待感によるものだが、実際の治療効果 もある可能性が非常に高いということ だ」という。この研究成果を報告した論 文は、Neurolmage1に掲載された。

Lewith は自分自身の過去の研究にお いて、鍼治療の効用の一部は期待感に よることがすでに示されていたと付言 している。その研究では、頝部に慢性的 な痛みのある被験者が対象になってお り、痛みの緩和効果の約 $80 \%$ が偽薬効 果であることが明らかにされていた 2

「Lewith たちの研究は、今後、より 適切な鍼治療の臨床試験を計画するう えで役立つだろう。この研究は、鍼治 療の考えられうる作用メカニズムを明 らかにしている」とKaptchukは語って いる。

\section{参考文献}

1. Pariente J., White P., Frackowiak, Richard S. J. \& Lewith G. Neuroimage,

25. 1161 - 1167 (2005)

2. White P., Lewith G., Prescott P. \& Conway J. Ann. Intern. Med., 141. 911 - 919 (2004). 